\title{
Evaluation of Nutritional Status in Elderly Patients with NRS-2002 Screening Test and Comparison of Results with Laboratory Parameters
}

\author{
Aydan Çevik ${ }^{1 *}$, Dilek Toprak ${ }^{2}$ \\ ${ }^{1}$ Community Health Center, Tekirdăg, Turkey \\ ${ }^{2}$ Ministry of Health, Şişli Hamidiye Etfal Training and Research Hospital, Family Medicine Department, \\ Istanbul, Turkey
}

Received: 12-06-2018 / Revised: 30-06-2018 / Accepted: 20-07-2018

\begin{abstract}
Background: Nutritional deficiencies are more common in the elderly who receive home care services than general elderly population. Objectives: In this study, it is aimed to investigate the relationship between nutritional status of elderly patients receiving home health care services and laboratory parameters. Methods: This study included 178 patients who agreed to participate in the program from a 65 -year-old or older patient at the home health care program. The methodology applied the nutritional risk scanning evaluation form as a face-to-face study. Data were evaluated a significance level of $\mathrm{p}<0.05$. Results: The ages of the subjects participating in the study ranged from 65 to 103 years. According to the total values of NRS-2002, 34.3\% were undernourished, and $73 \%$ had a risk of malnutrition. The NRS-2002 total classification laboratory test values have a statistically significant difference $(\mathrm{p}<0.01)$.The study detected low total protein, albumin, iron, total iron-binding capacity, folic acid and high vitamin $\mathrm{B}_{12}$ at a meaningful and high level $(\mathrm{p}<0.05)$ in the non-risk cases. C-reactive protein was significantly higher, and high triglyceride levels were significantly lower $(\mathrm{p}<0.05)$.Conclusions: Elderly patients who need health care at home should undergo extensive laboratory tests and physical examinations that asses anamnesis, physical and mental functions, and should receive screening specifically for the risk of malnutrition.
\end{abstract}

Keywords: Nutrition, NRS-2002 screening test, laboratory parameters.

\section{Introduction}

\section{Background}

The malnutrition term refers to a subacute or chronic undernourishment that involves inadequate nutrition and inflammatory activity, which results in changes in body composition and loss of function [1]. Lack of these, lead to respiration and malfunction of mental \& physical functions. These also cause reduced muscle strength and strength in individuals. The weakening of immunity increases the susceptibility to infections and the ability to cope with trauma and infection is reduced. Besides, wound healing is delayed and the progression of pressure sore is increased. Good nutrition improves people's quality of life.

*Correspondence

Aydan Çevik

Community Health Center, Tekirdağ, Turkey.

E- Mail: dracevik@gmail.com
At the same time, sensory and psychological satisfaction increase [2]. Good nutrition improves people's quality of life. At the same time, sensual and psychological satisfaction increase in well-fed people. In addition, good nutrition provides people to feel mentally and physically well [2].Today, $37-40 \%$ of aged individuals cannot feed on their daily energy needs, and two out of three aged people skip one meal in a day $[3,4]$.The mortality rate increases by $9-38 \%$ within 1-2.5 years after weight loss due to any reason[5].The deterioration of malnutrition affects every age group differently. This situation leads to more serious consequences, especially in geriatric individuals. If these type of individuals are not diagnosed, screened, and treated for malnutrition, treatment of other existing clinical diseases become difficult as well. Complications arise related to the health of the patient and this situation increases the morbidity and mortality, makes difficult of the 
physician's condition [6-9]. Many malnutrition screening methods have been developed in last decade to determine malnutrition grade in patients. Using these methods, findings such as energy loss, nutrient intake, appetite, fluid balance, gastrointestinal symptoms are evaluated. The results of these tests help the clinician to choose the appropriate treatment approach to the patient and to predict the course of the patient's condition[10,11].In this study, it is aimed to investigate the relationship between nutritional status of elderly patients receiving home health care services and laboratory parameters.

Methods

\section{Characteristics of patients and ethics}

This study included 178 patients aged 65 years and over who agreed to participate in this study and received Home Health Care between 08.01.2013 and 01.01.2014. This study have the approval of the Şişli Hamidiye Etfal Training and Research Hospital ethic committee

\section{Evaluation of data}

According to the NRS2002 evaluation form applied to the study participant, the test scores were evaluated as one is normal, two is malnutrition risk and below and is malnutrition.

\section{Statistical analysis}

For the statistical analyzes, descriptive statistical methods (Mean, Standard deviation, median, frequency, ratio) as well as the Oneway Anova test was used in the intergroup comparisons. Tukey HDS test was used to identify the group of differences. Pearson's Chi-square test, Yates Continuity Correction test, Fisher's Exact test and Fisher-Freeman Halton test were used for the comparison of qualitative data. The results were evaluated in a confidence interval of $95 \%$ and a significance level of $\mathrm{p}<0.05$.

\section{Results}

The ages of the participants in the study ranged from 65 to 103 years with an average of $81,19 \pm 8,22$ years. $32 \%$ of the participants were male and $68 \%$ were female. When the body mass index (BMI) levels of the cases are examined; $11.8 \%$ were found to be weak and $67.4 \%$ were obese. The measurements show that $18.5 \%$ of the cases had an inadequate level of chard perimeter and $16.9 \%$ had an inadequate level of calf perimeter (Table 1).

Table 1: Distribution of descriptive characteristics

\begin{tabular}{|l|l|l|}
\hline Age (year) & Min-Max (Median) & $\mathbf{6 5 - 1 0 3 ~ ( 8 1 . 5 )}$ \\
\hline & $A v g \pm S d$ & $81.19 \pm 8.22$ \\
\hline Gender; n (\%) & Female & $121(68.0)$ \\
\hline & Male & $57(32.0)$ \\
\hline BMI $\left(\mathrm{kg} / \mathrm{m}^{2}\right) ; \mathrm{n}(\%)$ & Weak & $21(11.8)$ \\
\hline & Normal & $37(20.8)$ \\
\hline & Obese & $120(67.4)$ \\
\hline Perimeter of Chard; n (\%) & Few & $30(16.9)$ \\
\hline Perimeter of Calf; $\mathrm{n}(\%)$ & Normal & $148(83.1)$ \\
\hline & Few & $33(18.5)$ \\
\hline & Normal & $145(81.5)$ \\
\hline
\end{tabular}

$n$ : number of patients in the group

According to the NRS-2002 classification, $34.3 \%$ of the cases were malnourished and $73 \%$ of the cases were at risk (Table 2).

Table 2: Risk assessment according to NRS2002 screening test result

\begin{tabular}{|l|c|c|}
\hline Min-Max & n & Avg \pm Sd \% \\
\hline None & 105 & 59.0 \\
\hline Repetitive & 12 & 6.7 \\
\hline At risk & 61 & 34.3 \\
\hline Low Risk & 130 & 73.0 \\
\hline
\end{tabular}

$n$ : number of patients in the group

According to the NRS-2002 classification results, there was no statistically significant difference between the gender distributions of the cases ( $p>0.05$ ). However, the number of male cases in the risk group is remarkable (Table 3 ). 
Table 3: Gender screening evaluation according to NRS-2002

\begin{tabular}{|c|c|c|c|}
\hline At risk (N=61) & Repetitive(N=12) & None(N=105) & ${ }^{{ }^{\mathbf{A}} \mathbf{p}}$ \\
\hline $\mathrm{n}(\%)$ & $\mathbf{n}(\boldsymbol{\%})$ & $\mathbf{n}(\boldsymbol{\%})$ & \\
\hline $35(57.4)$ & $8(66.7)$ & $78(74.3)$ & $\mathbf{0 . 0 7 9}$ \\
\hline $26(42.6)$ & $4(33.3)$ & $27(25.7)$ & \\
\hline
\end{tabular}

${ }^{a}$ Pearson Chi square test, ** $p<0.01, N$ : total number of patients, $n$ : number of patient

According to NRS-2002 classification, the distribution of total protein, albumin, iron, iron binding, ferritin, $\mathrm{B}_{12}$, folic acid levels showed statistically significant differences $(\mathrm{p}<0.05)$. Low total protein, albumin, iron, TDBC, folic acid and high $B_{12}$ vitamin results were significantly higher in the non-risk group $(\mathrm{p}<0.05)($ Table 4$)$.

Table 4: Evaluation of biochemical variables according to NRS-2002

\begin{tabular}{|c|c|c|c|c|c|}
\hline & At $\operatorname{Risk}(\mathrm{N}=61)$ & Repetitive (N=12) & None $(\mathrm{N}=105)$ & ${ }^{\mathbf{a}} \mathbf{p}$ \\
\hline & & $\mathrm{n}(\%)$ & $\mathrm{n}(\%)$ & $\mathrm{n}(\%)$ & \\
\hline \multirow[t]{2}{*}{ T.Protein } & Low & $42(68.9)$ & $5(41.7)$ & $12(11.4)$ & \multirow[t]{2}{*}{$0.001 * *$} \\
\hline & Normal & $19(31.1)$ & $7(58.3)$ & $93(88.6)$ & \\
\hline \multirow[t]{2}{*}{ Albumin } & Low & $37(60.7)$ & $5(41.7)$ & $7(6.7)$ & \multirow[t]{2}{*}{$0.001 * *$} \\
\hline & Normal & $24(39.3)$ & $7(58.3)$ & $98(93.3)$ & \\
\hline \multirow[t]{2}{*}{ Iron } & Low & $48(78.7)$ & $6(50.0)$ & $25(23.8)$ & \multirow[t]{2}{*}{$0.001 * *$} \\
\hline & Normal & $13(21.3)$ & $6(50.0)$ & $80(76.2)$ & \\
\hline \multirow[t]{2}{*}{ TDBK } & Low & $15(24.6)$ & $2(16.7)$ & $8(7.6)$ & \multirow[t]{2}{*}{$0.010 *$} \\
\hline & Normal & $46(75.4)$ & $10(83.3)$ & $97(92.4)$ & \\
\hline \multirow[t]{3}{*}{ Ferritin } & Low & 0 & 0 & $3(2.9)$ & \multirow[t]{3}{*}{$0.001 * *$} \\
\hline & Normal & $39(63.9)$ & $10(83.3)$ & $94(89.5)$ & \\
\hline & High & $22(36.1)$ & $2(16.7)$ & $8(7.6)$ & \\
\hline \multirow[t]{2}{*}{$\mathrm{B}_{12}$} & Low & $28(45.9)$ & $4(33.3)$ & $15(14.3)$ & \multirow[t]{2}{*}{$0.001 * *$} \\
\hline & Normal & $33(54.1)$ & $8(66.7)$ & $90(85.7)$ & \\
\hline \multirow[t]{2}{*}{ Folic acid } & Low & $27(44.3)$ & $5(41.7)$ & $22(21.0)$ & \multirow[t]{2}{*}{$0.005 * *$} \\
\hline & Normal & $34(55.7)$ & $7(58.3)$ & $83(79.0)$ & \\
\hline
\end{tabular}

${ }^{a}$ Pearson Chi square test, $* * p<0.01, N$ : total number of patients, $n$ : number of patient

According to the NRS-2002 classification, the distribution of CRP, low hemoglobin, high urea, cholesterol, triglyceride, AST, ALT levels showed a statistically significant difference $(\mathrm{p}<0.01)$. In the risk group, CRP was significantly high and triglyceride levels were significantly low $(\mathrm{p}<0.01)$. Low hemoglobin, high urea, cholesterol, ALT, AST levels

Table 5: Evaluation of NRS2002 and other measurements

\begin{tabular}{|c|c|c|c|c|c|}
\hline & At $\operatorname{risk}(\mathrm{N}=61)$ & Repetetive(N=12) & None $(\mathrm{N}=105)$ & ${ }^{a} \mathbf{p}$ \\
\hline & & $\mathrm{n}(\%)$ & $\mathrm{n}(\%)$ & $\mathrm{n}(\%)$ & \\
\hline \multirow[t]{2}{*}{ CRP } & Normal & $20(32.8)$ & $9(75.0)$ & $71(67.6)$ & \multirow[t]{2}{*}{$\mathbf{0 , 0 0 1} * *$} \\
\hline & High & $41(67.2)$ & $3(25.0)$ & $34(32.4)$ & \\
\hline \multirow[t]{2}{*}{ TSH } & Normal & $59(96.7)$ & $11(91.7)$ & $102(97.1)$ & \multirow[t]{2}{*}{${ }^{\mathrm{b}} 0.473$} \\
\hline & High & $2(3.3)$ & $1(8.3)$ & $3(2.9)$ & \\
\hline \multirow[t]{2}{*}{ HGB } & Low & $46(75.4)$ & $7(58.3)$ & $32(30.5)$ & \multirow[t]{2}{*}{$0.001 * *$} \\
\hline & Normal & $15(24.6)$ & $5(41.7)$ & $73(69.5)$ & \\
\hline \multirow[t]{2}{*}{ Lymphocyte } & Low & $30(49.2)$ & $5(41.7)$ & $35(33.3)$ & \multirow[t]{2}{*}{0,129} \\
\hline & Normal & $31(50.8)$ & $7(58.3)$ & $70(66.7)$ & \\
\hline \multirow[t]{2}{*}{ Urea } & Normal & $39(63.9)$ & $10(83.3)$ & $84(80.0)$ & \multirow[t]{2}{*}{${ }^{b} 0.062$} \\
\hline & High & $22(36.1)$ & $2(16.7)$ & $21(20.0)$ & \\
\hline
\end{tabular}

\section{Cevik and Toprak}

ASIAN PACIFIC JOURNAL OF HEALTH SCIENCES, 2018; 5(3):25-30 


\begin{tabular}{|c|c|c|c|c|c|}
\hline \multirow{2}{*}{ Creatinine } & Normal & $33(54.1)$ & $8(66.7)$ & 65 (61.9) & \multirow[t]{2}{*}{0.536} \\
\hline & High & $28(45.9)$ & $4(33.3)$ & $40(38.1)$ & \\
\hline \multirow[t]{2}{*}{ Cholesterol } & Normal & $52(85.2)$ & $11(91.7)$ & $55(52.4)$ & \multirow[t]{2}{*}{$0.001 * *$} \\
\hline & High & $9(14.8)$ & $1(8.3)$ & $50(47.6)$ & \\
\hline \multirow[t]{2}{*}{ Triglycerides } & Normal & $61(100.0)$ & $12(100.0)$ & $91(86.7)$ & \multirow{2}{*}{$\begin{array}{l}\text { b0.003* } \\
*\end{array}$} \\
\hline & High & 0 & 0 & $14(13.3)$ & \\
\hline \multirow[t]{2}{*}{$\mathrm{HDL}$} & Low & $38(62.3)$ & $6(50.0)$ & $52(49.5)$ & \multirow[t]{2}{*}{0.271} \\
\hline & Normal & $23(37.7)$ & $6(50.0)$ & $53(50.5)$ & \\
\hline \multirow[t]{2}{*}{ AST } & Normal & $49(80.3)$ & $12(100.0)$ & 99 (94.3) & \multirow[t]{2}{*}{$0.008 * *$} \\
\hline & High & $12(19.7)$ & 0 & $6(5.7)$ & \\
\hline \multirow[t]{2}{*}{ ALT } & Normal & $48(78.7)$ & $12(100.0)$ & $100(95.2)$ & \multirow[t]{2}{*}{$0.001 * *$} \\
\hline & High & $13(21.3)$ & 0 & $5(4.8)$ & \\
\hline
\end{tabular}

${ }^{a}$ Pearson Chi square test, ${ }^{b}$ Fisher Freeman Halton Test $*, p<0,05 * * p<0,01, N$ : Total number of patients, $n$ :

Number of patient

\section{Discussion}

ESPEN (European Society of Clinical Nutrition and Metabolism), recommends routine screening of all individuals over the age of 65 in a nutritional way. ${ }^{16}$ Studies in the screening and prevention of malnutrition in the geriatric patient group are increasing. The work done in this area has become more concentrated on the outpatient clinic or hospitalized patients. However, the number of studies is limited on the geriatric patient group, which needs home health care in our country. it is recommended all of this patient group should be screened early and appropriate patients should be treated. There has been an increase in the monitor-up of undernutrition in country in recent years, the number of these studies on patients receiving home care services is limited. In this study, geriatric patients who received home care services were found to have malnitrition at a high rate $(34.3 \%)$ and to be under the risk of malnitrition $(73 \%)$. There was no statistically significant difference in malnutrition ratio between males and females (p>0.05). Prevalence of undernutrition in elderly people is reported to be 2$32 \%$ in healthy individuals, $15 \%$ in home-dependent elderly, 30-60\% in residents in various institutions, and $23-65 \%$ in inpatients[17-21].The rate malnutrition is reported in $71.24 \%$ of geriatric patients in hospital intensive care unit, and $13.8 \%$ in nursing home residents[17,22]. In a study conducted in rural Finland, it is reported that $3 \%$ of elderly individuals receiving home health care to be malnourished and $48 \%$ were at risk of malnutrition[6].In a large literature review conducted by Guigoz, it was found that the prevalence of malnutrition in the community was $2 \%$ and the risk of malnutrition was $24 \%$ [23]. In a study conducted in outpatient clinics in our country, the rate of malnutrition in geriatric individuals was $2.1-1.3 \%$ and the risk of malnutrition was $14.3-49.2 \%[7,16,24,25]$ In two cross-sectional studies reported with the screening of elderly people in a nursing home in Istanbul, the rate of malnutrition was $9.8 \%$ and the risk of malnutrition was $22.8 \%$ [26]. It is stated that the rate of malnutrition in home-based health services is as high as this study. This study is a single-center (only one hospital) and only includes home-based health care co-operation and orientation group that includes a sufficient number of patients with no swallowing difficulty, more than one month of survival expectancy, and no psychotic disorder. The high value results obtained in the geriatric age group are due to unconsciousness of the patients and their families, having low socioeconomic levels, and their lack of knowledge of appropriate nutritional techniques. Nutrition does not mean only eating large amounts of food or eating always a single kind of food. Moreover, skipping the meals is not nutrition. Caregivers who take care of the patients should help them to feed frequently but less amount and patiently.Among the parameters that can be used to determine the degree of malnourishment in the aged population are anthropometric measurements and laboratory evaluations as well. Using other acceptable anthropometric measures such as body mass index (BMI) calculations, calf measurement, skin fold thickness measurements provide extra contributions to understand to the underlying causes of malnutrition and malnutrition. Indirect calorimetry is the best method of determining patients' energy needs, although not so common in everyday practice. At this point, laboratory tests help the clinician $[1,12,13]$. Laboratory tests such as whole blood count, serum albumin, and c-reactive protein give an idea to the clinician about the traumatic and inflammatory diseases that represent the catabolic phase $[4,14,15]$. Routine tests of liver enzyme, creatinine, urea and lipid level measurement are suggested for screening of malnutrition. In the diagnosis of gastrointestinal disease, iron levels, Creactive protein are useful for evaluating acute inflammatory activity test[1].Nutrition screening tests 
are very important in the geriatric age group. In addition, anthropometric and laboratory results, which provide information to the clinician about increased body catabolism with trauma and inflammatory diseases are also considerable[2,13,17,22,27]. In this study, a statistically significant correlation was found between the laboratory tests according to the NRS2002 classification results $(\mathrm{p}<0.05)$. However, there was no statistically significant difference in the distribution of lymphocytes, creatinine, TSH, HDL levels. Low total protein, albumin, iron, TDBC, folic acid and high $B_{12}$ vitamin results were significantly high in non-risk cases $(\mathrm{p}<0.05)$. Low total protein, albumin, iron, TDBC, and folic acid levels are also low in patients with malnutrition. The most commonly used and effective parameter which affects the result of a scan test is the albumin, and it is used frequently despite its having low sensitivity and selectivity. It should be known that the albumin level may be close to normal values even in humans with malnutrition despite adequate intake of nutrients. And also, the level of serum albumin is affected by the distribution and dilution[13,19,26,27]. In malnutrition, hemoglobin, iron, TDBC, B-12, folic acid and lymphocyte ratios decrease while ferritin and CRP levels increase.In studies conducted in our country, low levels of albumin have been associated with the risk of malnutrition. ${ }^{16}$ The results of current food consumption surveys indicate that there is a lack of energy, protein, B vitamins and minerals such as iron in the elderly living in homes and in nursing homes. Although the incidence of folate and vitamin $\mathrm{B}_{12}$ deficiency is unknown for the elderly in the whole population, it is known that these two vitamin deficiencies are an important reason for the formation of cardiovascular diseases in later ages. Among the causes leading to malnutrition, trauma and inflammation are important factors in diseases as well as food supply. Insufficient food intake can be more easily rectified from these factors[4,14,15]. In this study, in order to obtain the results of nearmalnourishing: Patients with psychotic disorders, trouble of swallowing, less than one month of survival expectancy, parenteral and enteral nutritional disorders were not included in this study, but have an adequate orientation and co-operation ones were included in the study.The right choice of malnutrition screening tests to be applied to the disease is very important. Improper testing leads to the incorrect intervention for patients. Incorrect intervention and delay cause resources to be wasted[28]. This test is recommended for malnutrition in adult and elderly individuals, which can be performed in a short time and is compatible with many patient groups[14]. Another screening test recommended for this patient group is MNA. The NRS 2002 was selected as a screening test in order to reliably determine the mortality of the patient as fast, effective and cheap. ESPEN also recommends this test, widely used in Europe, for the evaluation of nutritional risk of inpatients[10,11,29]. In addition, this test provides information about the risks that may arise from the fierceness of the present disease[30]. We chose the NRS-2002 test because the patients that we used as subjects were receiving home care services. Although MNA is a sensitive test, it is not a disadvantage that we did not use this test[31,32]. It is because, more malnitrition risk was detected in our study than in studies using MNA test in patients.

Malnutrition in geriatric individuals does not only lead to weight loss and changes in body composition, but also to undesirable conditions such as impaired physiological functions, increased risk for complications and poor clinical outcomes. Changes in body structure, physical-mental and organ functions can be seen in proportion of the degree and severity of dietary insufficiency. If a patient is diagnosed with malnutrition and is not treated, the treatment of other diseases becomes difficult. In addition, it increases morbidity and mortality in geriatric patients by increasing various complications. We recommend that malnutrition is a common clinical condition for patients in the geriatric age group who are in need of home health care. All of these patients should be thoroughly assessed with malnutrition screening and appropriate laboratory tests and screened for risk of malnutrition.

\section{Acknowledgements}

I thank to Associate Professor Okcan Basat at Gaziosman Paşa Research Hospital, Istanbul,Turkey.

\section{References}

1. Soeters PB, Reijven PL, van Bokhorst-de van der Schueren MA, Schols JM, Halfens RJ, Meijers JM et al. A rational approach to nutritional assessment. Clin nutr 2008; 27: 706-716

2. Sobotka L, Gündoğdu H. (Ed.) Klinik Nutrisyonun Temelleri. Ankara, 21-32: 2013.

3. Morley JE. Anorexia of aging: Physiologic and pathologic. Am J Clin Nutr 1997; 66: 760-773

4. Norman $\mathrm{K}$, Pichard $\mathrm{C}$, Lochs $\mathrm{H}$, Pirlich $\mathrm{M}$. Prognostic impact of disease-related malnutrition. Clin Nutr 2008; 27: 5-15

5. Marton KI, Sox HC Jr, Krupp JR. Involuntary weight loss: diagnostic and prognostic significance. Ann Intern Med 1981; 95: 568-74 
6. Soini $\mathrm{H}$, Routasalo $\mathrm{P}$ and Lagström $\mathrm{H}$. Characteristics of the Mini-Nutritional Assessment in elderly home-care patients. Eur J Clin Nutr 2004; 58: $64-70$

7. Şahin H., Çicek B, Yılmaz M, Organ D, Kaya N, İnanç N. Determining Nutritional Status And Quality of Life Of 65 Years and Oder Individuals in Kayseri. Turkish J of Geriatr 2013; 16 (3): 322-329

8. Saka B, Kaya O, Ozturk GB, Erten N, Karan MA. Malnutrition in the elderly and its relationship with other geriatric syndromes. Clin Nutr 2010; 29: 745-8

9. Demir MV, Tamer A, Cinemre H, I Uslan, Yaylacı S, Erkorkmaz U. Nutritional status and laboratory parameters among internal medicine inpatients. Niger J Clin Pract. 2015; 18 (6): 757-76

10. Kondrup J, Rasmussen H, Hamberg O, Stanga Z.. Nutritional Risk Screening (NRS-2002): a new method based on analysis of controlled clinical trials. Clin Nutr 2003; 22: 321-336

11. Green SM, Watson $R$. Nutritional screening and assessment tools for older adults: literature review. J Adv Nurs 2006; 54: 477-490

12. Weijs PJ, Kruizenga HM, van Dijk $\mathrm{AE}$ et al. Validation of predictive equations for resting energy expenditure in adult outpatients and inpatients. Clin Nutr 2008; 27: 150-157

13. Johson LE, Sullivan DE. Nutrition and failure to thrive. In: Landefeld CS, Palmer RM, Johnson MA, Johnston CB, Lyons WL, editors. Currrent geriatric treatment and diagnosis. International ed. New York: Mc Graw Hill Companies 2004

14. Jahoor F, Badaloo A, Reid M, Forrester T. Protein kinetik differences between children with edematous and nonedematous severe childhood undernutrition in the fed and postabsorptive states. Am J Clin Nutr 2005; 82: 792-800

15. Kondrup J, Allison SP, Elia M, Vellas B, Plauth M. ESPEN guidelines for Nutrition Screening 2002. Clin Nutr 2003; 22: 415-21

16. Ulger Z, Halil M, Kalan I, Yavuz BB, Cankurtaran M, Güngör E, et al. Comprhensive assessment of malnutrition risk and related factors in a large group of community-dwelling older adults. Clin Nutr 2010; 29: 507-511

17. Kaiser MJ, Bauer JM, Ramsch C, Uter W, Guigoz Y, Cederholm T, Et al. Mini-Nutritional Assessment International Group. Frequency of malnutrition in older adults: a multinational perspective using the mini nutritional assessment. J Am Geriatr Soc 2010; 58: $1734-1738$

18. Rakıcıoğlu N. Yaşlılık döneminde malnütrisyonun saptanması.Yaşlilarda Malnütrisyon Klavuzu 2013: $115-120$

Conflict of Interest: None

Source of Support: Nil
19. Seiler WO. Clinical pictures of malnutrition in ill elderly subjects. Nutrition 2001; 17: 496-8.

20. Niedert KC. Position of the American Dietetic Association: Liberalized diets for older adults in long term care. J Am Diet Assoc 2005; 105: 1955-65

21. Crogan NL,PasvogelA.The influence of proteincalorie malnutrition on quality of life in nursing homes. J Gerontol A Biol Sci Med Sci 2003; 58: 15964.

22. Shpata V, Ohri I, Nurka T, Prendushi $X$. The prevalence and consequences of malnutrition risk in elderly Albanian intensive care unit patients. Clin Interv Aging 2015: 10: 481-486

23. Guigoz Y. The Mini Nutritional Assessment (MNA) review of the literature-what does it tell us? J Nutr Health Aging 2006; 10: 466-85

24. Saka B, Kaya O, Ozturk GB, Erten N, Karan MA. Malnutrition in the elderly and its relationship with other geriatric syndromes. Clin Nutr 2010; 29(6): 745-748

25. Saka B, Özkuluk H. Evaluation of the nutritional status and relationship of malnutrition with other geriatric syndromes in elderly patients who admitted to the internal medicine outpatient clinic Gulhane Medic Jour 2008; 50: 151-7

26. Akan $\mathrm{H}$, Ayraler A, Hayran O. Nutritional status of elderlies admitted to home health care service. Türk Aile Hek Derg 2013; 17(3): 106-112

27. Omran ML, Salem P. Diagnosing undernutrition. Clin Geriatr Med 2002; 18: 719-36

28. Demirel U, Aygün C. Importance of Nutritional Status of Hospitalized Patients and Estimation of Calory Requirement. Firat Tip Derg 2012; 17 (2): 063-070

29. Kaiser MJ, Bauer JM, Ramsch $\mathrm{C}$ et al. Validation of the mini nutritional assessment short form (MNA$\mathrm{SF})$ : a practical tool for identification of nutritional status. J Nutr Health Aging 2009; 13: 782-788

30. Raslan M, Gonzalez MC, Gonçalves Dias MC et al. Comparison of nutritional risk screening tools for predicting clinical outcomes in hospitalized patients. Nutrition 2010; 26: 721-6

31. Bauer JM, Vogl T, Wicklein S, Trögner J, Mühlberg W, Sieber CC. Comparison of the Mini Nutritional Assessment, Subjective Global Assessment, and Nutritional Risk Screening (NRS 2002) for nutritional screening and assessment in geriatric hospital patients. Z Gerontol Geriatri 2005; 38(5): 322-7

32. Kyle UG, Kossovsky MP, Karsegard VL, Pichard C. Comparison of tools for nutritional assessment and screening at hospital admission: a population study. Clin Nutr 2006; 25; 409-417. 